\title{
Development of an instrument to measure EFL teachers' perceptions of reflective teaching
}

\author{
Rokhsareh Ghorbani Moghaddam \\ Department of English Language and Literature, Faculty of Literature and Humanities, \\ Hakim Sabzevari University, Sabzevar, Iran
}

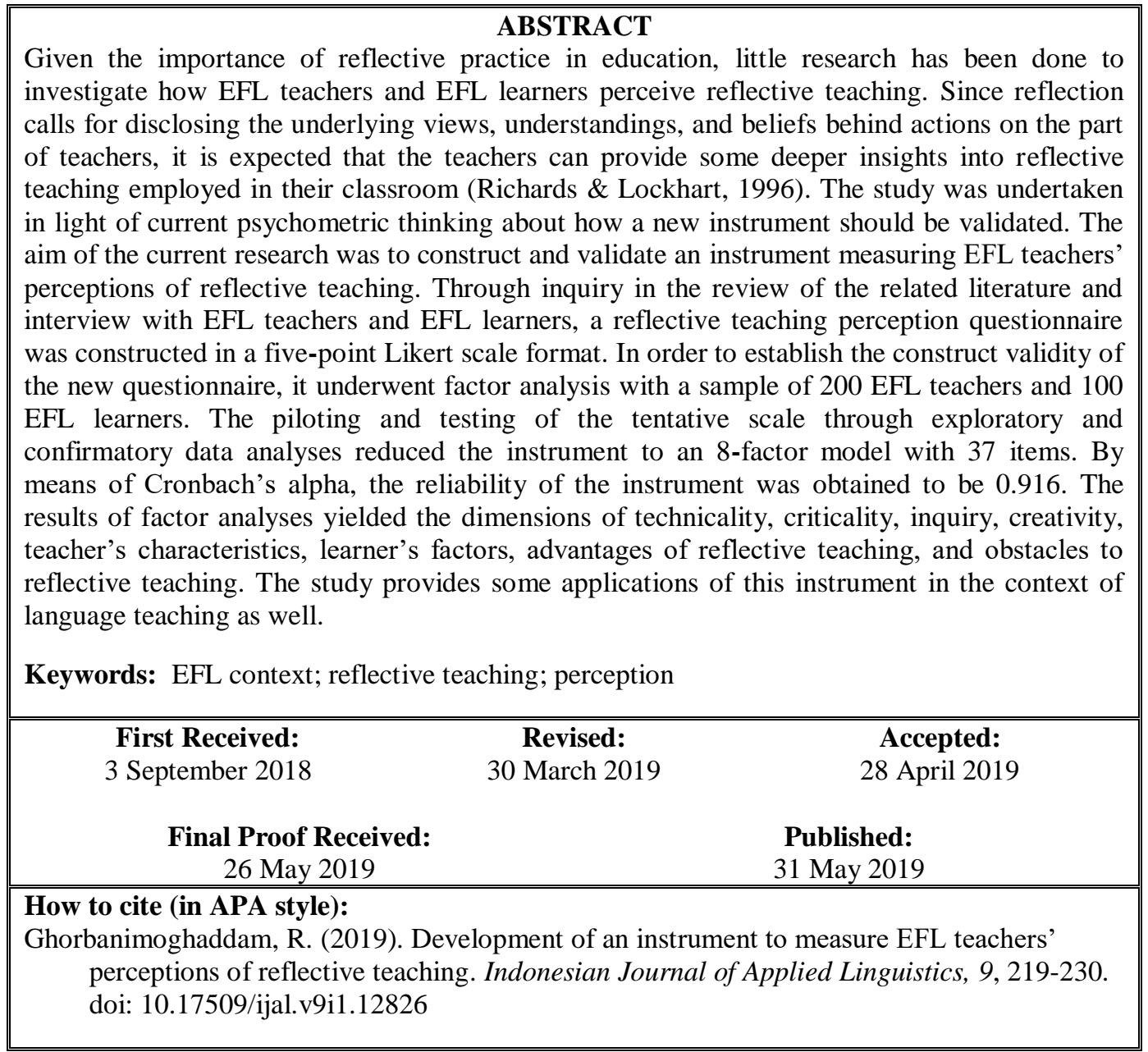

\section{INTRODUCTION}

Described as a hallmark of professional development, reflection or reflective practice has not been defined clearly in teacher education literature. The absence of a clear-cut definition has to do with the complexity of the reflection action per se and the impact of different philosophies and disciplines on its origin (Akbari, 2007). Despite the absence of an omnibus definition for reflection, it has gained momentum and attracted huge attention in many areas particularly teaching. Reflective practice is defined by its forerunners (Dewey, 1933;
Schön, 1987) as an action that emancipates the practitioner from the impulsive, habitual one with the intention of changing practice.

Given the importance of reflective practice in education, little research has been done to investigate how EFL teachers and EFL learners perceive reflective teaching. Since reflection calls for disclosing the underlying views, understandings, and beliefs behind actions on the part of teachers, it is expected that the teachers can provide some deeper insights into reflective teaching employed in their classroom 
(Richards \& Lockhart, 1996). Not to mention that significance of teachers' opinions and understandings about teaching as well as eliciting their beliefs and assumptions serves "as interpretive lenses through which beginning teachers make sense of their experience" (Alger, 2006, p. 288). Teaching as Richards and Lockhart (1996) maintain, is a personal profession which permits teachers to bring their different personal assumptions about teaching; such views function as the background for the teachers' decision making and action, and hence guide and construct "the culture of teaching" (p. 30). Lack of an instrument to measure their attitude is highly remarkable in the pertinent review. The present study, therefore, seeks to design a scale to measure EFL teachers' and EFL learners' perceptions of reflective teaching. Awareness of the teachers' perceptions in this regard is particularly important as they have their own teaching philosophy, identity, and skills which may contribute to capturing a holistic picture of reflective teaching. Equally importantly, in order to improve teaching and learners' achievement, capturing learners' beliefs and perceptions should not be ignored. As Williams and Burden (1997) postulate, "learners' perceptions and interpretations . . . have been found to have the greatest influence on achievement" (p. 98).

Reflective teaching is frequently recognized as a cornerstone of professional development in the field of education and has become a major paradigm in educating (Farrell, 2004; Schön, 1987). Reflective teaching requires teachers to analyze the process of what they are doing and to reconstruct their knowledge schemes, critically appraising their own responses to practice situations while simultaneously making a decision to adjust their practice to match the needs of students (Schön, 1987).

Reflection is not uni-dimensional rather a holistic approach encompassing the intellectual, cognitive and metacognitive, the spiritual, moral, and emotional aspects of teaching. Put it in another way, reflective practice is not restricted to analysis and evaluation of teaching values and beliefs rather it involves reflection beyond teaching and learning (Farrell, 2004). Adopting reflective practice requires teachers to collect data and ponder over their actions to enhance their teaching practices (Farrell, 2007).

The existing literature has identified the components of reflection as technical rationality, practical reflection, and critical reflection (Van Manen, 1977). According to the literature (Bartlett, 1990; Pedro, 2005), in order for teachers to cultivate the reflective mindset, they should think critically about their practice and ponder on it, examine them in light with the historical, social, and cultural contexts where they actually practice their teaching (Bartlett, 1990, p. 205); they need to take into account "questioning and problem-solving as two ways that enable them to become reflective about their actions in the classroom" (Pedro, 2005, p. 57).
Reflection embraces critical thinking, metacognitive thinking, problem-solving, and creative thinking. Teaching without reflection leads to conformity and routinized practice, which can hinder creating novel insights (Farrell, 2007). The advantage of reflective practice is that it paves the way toward teachers' enhanced professionalism and selfdevelopment through cognitive, affective changes in their learning, their development, and their socialization. Alternatively, change in teachers and teaching through reflection might occur at procedural and interpersonal conceptual levels (Pennington, 1992). By adopting such changes, a teacher is expected to be equipped with a transformation of skills and instruction to the better lifelong learning (Richardson \& Placer, 2001; Shulman, 1987).

Of important characteristics of reflective teachers, as described by Dewey (1933), are open- mindedness (being open to different views), responsibility (being responsible for their action, being aware of the reverberations of any course of action taken in the practice setting, wholeheartedness (being eager and enthusiastic). According to Ghaye (2011), reflective teachers are characterized by good observation, selfawareness, and self-critique; they observe with "intense concentration in order to come to know what is going on in the (inter) actions or encounters in front of them and in which they are immersed" (p. 9). In other words, reflective teachers as self-critical persons take a critical position towards their practice in a manner that is productive rather destructive; with such a disposition they challenge the means and ends of education (Ghaye, 2011, p. 23). They go beyond primary instructional concerns to "how to" questions and ask "what" and "why" questions; they "transcend the technicalities of teaching and think beyond the need to improve instructional techniques" (Bartlett 1990, p.204), and take into account issues of justice, equity, and morality (Zeichner \& Liston, 1996). Putting reflective teaching into practice would be challenging and demanding since it requires the involvement of self, the students, the school, and society at large (Mathews, 2012).

Reflective teachers need to possess a substantial body of knowledge and a range of solutions to cope with a felt difficulty in different situations; as Dewey (1933) and Richards and Lockhart (1996) suggested, teachers need to collect data about their teaching, evaluate their attitudes, beliefs, assumptions, and teaching practices and use that information as a source for critical reflection. Despite a plethora of empirical study on reflective teaching, there is a scarcity of research over developing an instrument measuring teachers' perceptions of reflective teaching. Previous scales have been developed either in L1 context (e.g.,Young, 1989) or for different purposes (e.g., Kayapınar \& Erkus, 2009; Kember et al., 2000), thus their suitability for other contexts and other purposes is questionable. According to Farhady, Hezaveh, and Hedayati (2010), it is not possible to for two educational communities to be managed similarly, because they do 
not enjoy the same features. "Implementing even a single theory in two different contexts would lead to different procedures and outcomes" (Farhady, Hezaveh, \& Hedayati, 2010, p. 14). The present study, therefore, sets out to devise an instrument to measure EFL teachers' perceptions in L2 context.

The current research, therefore, deals with investigation on whether the newly developed questionnaire on teachers' perceptions of reflective teaching enjoys acceptable psychometric properties (reliability and validity).

\section{METHOD}

The current research elaborates the development and validation process of an instrument measuring teachers' perceptions of reflective teaching.

\section{Instrument}

A researcher-made questionnaire in five-point Likert scale format was designed and administered to $200 \mathrm{EFL}$ teachers and 100 EFL learners.

\section{Participants and sampling for questionnaire development}

The participants for the present study were a random sample of $100 \mathrm{EFL}$ learners and 250 Iranian EFL teachers both males and females. Teachers had BA, MA., and Ph.D. degree in teaching English as a foreign language (TEFL), English literature, translation, and linguistics with years of teaching experiences ranging from 3 to more than 10 years. Learners were within the age range of 16 to 22 . The participants were asked to complete and return the questionnaire developed by the researcher. Table 1 illustrates the demographic characteristics of the participants.

Table 1. Demographic data of the participants for the questionnaire

\begin{tabular}{lcc}
\hline Demographic data & Number \\
\hline Gender & Learner & Teacher \\
Male & 20 & 120 \\
Female & 80 & 180 \\
Education degree & & - \\
Bachelor & 140 \\
Master & 55 \\
Ph.D. & 5 \\
Professional experience (years) & - \\
Less than one year & 0 \\
1-2 years & 0 \\
3-5 years & 20 \\
5-10 years & 60 \\
More than 10 years & 120 \\
\hline
\end{tabular}

\section{Procedures}

The main aim of the present research was to develop a novel instrument to assess EFL teachers' perceptions of reflective teaching in an EFL context. In so doing, the researcher designed a questionnaire according to the steps recommended by Dörnyei and Taguchi (2010), including developing an item generation based on constructs of reflective teaching cited in the literature and interview, initial piloting, content validity, back translation, second piloting, and psychometric properties. For item pooling stage, based on the review and interview data an accumulation of eight dimensions of reflective teaching along with 68 items was generated. Initially, questionnaire was drafted with 68 items under the dimensions of technicality, criticality, inquiry, creativity, teacher's characteristics, learner's factors, advantages of reflective teaching, and obstacles to reflective teaching. The researcher developed some items under each construct. Next, a panel of three EFL experts was invited to examine the content validity of the scale and revise the items. Following their feedback, some modifications were inserted in the questionnaire items. After that, the revised questionnaire was initially piloted with 5 EFL teachers and 3 EFL learners to examine the clarity of items. They were asked to mark any item whose wording they found ambiguous and unnecessary as well as give suggestions for an improvement if they like. Following their comments, irrelevant and double-barreled items were excluded and related statements were merged. Below presents some exemplars of the refinements:

1. Items 1, 2, 23, 28, 29 and 46 were rephrased due to their complexity stated by the respondents.

2. Items $16,22,24,26,30,36,48,50,51,61,64$, and 68 were deleted since they are ambiguous and unnecessary.

Following that, the items of the questionnaire were translated into Persian by the researcher to make sure of their consistency in both versions. Having been translated into Persian, the instrument was given to two doctoral Persian literature students to check its translation in terms of naturalness, fluency, and ambiguity. Some loaded and unnecessary words were deleted or edited according to their comments. After such editing, the researcher back-translated the Persian version of the questionnaire and gave it to the same 
panel of EFL experts to have a look at it. Following their approval, the final version of the instrument was polished through the second piloting with 50 participants as Dörnyei (2007) argues, to understand how the items would work in actual practice as well as to determine its reliability index. The reliability of the questionnaire was estimated using Cronbach's alpha coefficient whose value was 0.883 . As a result of the second pilot test, the items with low reliability indices were deleted. After discarding such items, the researcher prepared the final version of the questionnaire in a five-point Likert-scale format with 47 items ranging from very significant (5) to no significant (1). The results with means closer to 4 indicate the higher degree of importance that teachers and learners attach to both items and components in the questionnaire while the results closer to 1 suggest that the components and the items are not important.

The ultimate version of the questionnaire was subjected to a series of factor analysis using SPSS 23 and Lisrel 8 soft wares to determine its construct validity. Data collection was conducted by both manual distribution and by email distribution of the survey instrument. Out of the 350 copies of the questionnaire distributed, 300 had been properly completed and returned to the researcher to be used for data analysis. It should be mentioned that as the learners might not be proficient enough to understand English version of the questionnaire, the Persian version of questionnaire was distributed among them. In order to make sure of comprehensibility of the questionnaire for the learners, a panel of expert checked the wording and the content of the questionnaire, and approved it. The collected data were fed to SPSS version 23 and a series of factor analysis was carried out.

\section{FINDINGS AND DISCUSSION}

\section{Results of Exploratory Factor Analysis (EFA)}

Prior to implementing factor analysis, it was essential to establish the appropriateness of factor analysis through the Kaiser- Meyer-Olkin (KMO) sampling adequacy test and Bartlett's test of sphericity (Table 2). As Table 2 illustrates, the Kaiser-Meyer-Olkin value is .771, which is greater than the recommended value of 0.6 , and Bartlett's test of sphericity is significant $(\mathrm{p}<.05)$ (Pallant, 2011). The results, therefore, indicate that Exploratory Factor Analysis (EFA) is appropriate for identifying the number of latent constructs underlying the items of the questionnaire. Principal component analysis with varimax rotation was run whose results revealed 47 items with a correlation coefficient of higher than .3 which were initially loaded under 8 components. These components had eigenvalues above 1 which explain 24.652, 16.208, 8.088, 6.689, 6.039, $4.592,3.843$, and 3.439 , of the variance respectively in the questionnaire (Table 3). Also, in Figure 1, scree plot showed a break after the 8 components, which suggests that eight factors could be kept for the study. Cross- loadings were also discovered, however, as they were higher on one factor than the other one they were ignored. Following factor loading, the items that were not loaded on any factor needed to be discarded. At this phase, all items were loaded on 8 components (Table 4). Factor loadings $>0.3$ were considered to be significant for including the items in a factor (Pallant, 2011) and cross-loading more than 0.2 . Items $15,29,32,33,36$, 39 , and 40 with loadings smaller than 0.3 were removed from the instrument due to their low loading value. In addition, items 30 and 34 cross-loading with technical factors and teachers' characteristics were deleted. This left the resulting instrument with 37 items. The eight components are named based on the shared concepts in the items loaded under each factor. The first component is named technical dimension as the items in this component deals with mostly the technical aspects of teaching including the efficiency of instruction and the means than the ends in the classroom (Van Manen, 1977). The second component is inquiry as the seven items focus on the ways teachers tackle encountered problems. Reflection makes teachers ask themselves questions as a means of learning from their teaching context and seek solutions to the encountered problem in different ways (Farrell, 2007; Schön, 1987). The third component is named critical dimension as twelve items are about critical aspects. According to the principles of reflective teaching, teachers are to go beyond primary instructional concerns to "how to" questions and ask "what" and "why" questions; they "transcend the technicalities of teaching and think beyond the need to improve instructional techniques" (Bartlett 1990, p. 204), and take into account issues of justice, equity, and morality (Zeichner \& Liston, 1996). Component four is called creativity. The fifth component is named teachers' issues since the items in this part mostly focus on the characteristics of a reflective teacher. As the component six is about the learners' variables, it is called learners' factors. Items loaded on the merits and consequences of reflective teaching are clustered as the advantages component. According to the literature, reflection enables teachers to modify their shortcomings in any aspects of teaching in order to enhance students' learning and their own teaching practices (Richards \& Lockhart, 1996). Reflective practice brings about resourcefulness and resilience required to encounter future challenges and changes in profession (Farrell, 2015). Finally, the eighth component is named as the obstacles to reflective teaching as the items in this part deal with the barriers to reflective teaching. In short, the EFA presented an 8-factor model.

Table 2. KMO and Bartlett's test Kaiser-Meyer-Olkin Measure of Sampling .771 Adequacy.

Bartlett's Test of Sphericity Approx. Chi-Square 15451.443 Df 1035 Sig. $\quad .000$

Note $. \mathrm{df}=$ degree of freedom; sig = significance. 
Table 3.Total variance explained

\begin{tabular}{|c|c|c|c|c|c|c|c|c|c|}
\hline \multirow{2}{*}{ Component } & \multicolumn{3}{|c|}{$\underline{\text { Initial Eigenvalues }}$} & \multicolumn{3}{|c|}{$\frac{\text { Extraction Sums of Squared }}{\text { Loadings }}$} & \multicolumn{3}{|c|}{$\frac{\text { Rotation Sums of Squared }}{\text { Loadings }}$} \\
\hline & Total & $\begin{array}{c}\% \text { of } \\
\text { Variance }\end{array}$ & $\underset{\%}{\text { Cumulative }}$ & Total & $\begin{array}{c}\% \text { of } \\
\text { Variance }\end{array}$ & $\underset{\%}{\text { Cumulative }}$ & Total & $\begin{array}{c}\% \text { of } \\
\text { Variance }\end{array}$ & Cumulative \\
\hline 1 & 11.833 & 24.652 & 24.652 & 11.833 & 24.652 & 24.652 & 10.602 & 22.087 & 22.087 \\
\hline 2 & 7.780 & 16.208 & 40.860 & 7.780 & 16.208 & 40.860 & 6.588 & 13.725 & 35.812 \\
\hline 3 & 3.882 & 8.088 & 48.948 & 3.882 & 8.088 & 48.948 & 3.772 & 7.858 & 43.669 \\
\hline 4 & 3.210 & 6.689 & 55.637 & 3.210 & 6.689 & 55.637 & 3.730 & 7.771 & 51.440 \\
\hline 5 & 2.899 & 6.039 & 61.676 & 2.899 & 6.039 & 61.676 & 3.295 & 6.865 & 58.305 \\
\hline 6 & 2.204 & 4.592 & 66.268 & 2.204 & 4.592 & 66.268 & 3.091 & 6.440 & 64.746 \\
\hline 7 & 1.845 & 3.843 & 70.111 & 1.845 & 3.843 & 70.111 & 2.450 & 5.104 & 69.850 \\
\hline 8 & 1.651 & 3.439 & 73.550 & 1.651 & 3.439 & 73.550 & 1.776 & 3.701 & 73.550 \\
\hline 9 & .998 & 2.957 & 76.508 & & & & & & \\
\hline 10 & .985 & 2.198 & 78.705 & & & & & & \\
\hline 11 & .960 & 2.143 & 80.848 & & & & & & \\
\hline 12 & .950 & 1.979 & 82.827 & & & & & & \\
\hline 13 & .899 & 1.873 & 84.700 & & & & & & \\
\hline 14 & .828 & 1.724 & 86.424 & & & & & & \\
\hline 15 & .718 & 1.496 & 87.920 & & & & & & \\
\hline 16 & .566 & 1.180 & 89.100 & & & & & & \\
\hline 17 & .513 & 1.070 & 90.169 & & & & & & \\
\hline 18 & .467 & .973 & 91.143 & & & & & & \\
\hline 19 & .453 & .945 & 92.087 & & & & & & \\
\hline 20 & .385 & .802 & 92.889 & & & & & & \\
\hline 21 & .360 & .750 & 93.639 & & & & & & \\
\hline 22 & .323 & .673 & 94.312 & & & & & & \\
\hline 23 & .270 & .563 & 94.874 & & & & & & \\
\hline 24 & .256 & .533 & 95.407 & & & & & & \\
\hline 25 & .233 & .485 & 95.892 & & & & & & \\
\hline 26 & .206 & .430 & 96.322 & & & & & & \\
\hline 27 & .181 & .377 & 96.699 & & & & & & \\
\hline 28 & .167 & .348 & 97.048 & & & & & & \\
\hline 29 & .160 & .333 & 97.380 & & & & & & \\
\hline 30 & .150 & .312 & 97.692 & & & & & & \\
\hline 31 & .131 & .273 & 97.965 & & & & & & \\
\hline 32 & .119 & .249 & 98.214 & & & & & & \\
\hline 33 & .115 & .240 & 98.454 & & & & & & \\
\hline 34 & .092 & .192 & 98.646 & & & & & & \\
\hline 35 & .090 & .187 & 98.832 & & & & & & \\
\hline 36 & .086 & .179 & 99.012 & & & & & & \\
\hline 37 & .076 & .158 & 99.170 & & & & & & \\
\hline 38 & .065 & .135 & 99.305 & & & & & & \\
\hline 39 & .062 & .129 & 99.433 & & & & & & \\
\hline 40 & .053 & .110 & 99.544 & & & & & & \\
\hline 41 & .048 & .099 & 99.643 & & & & & & \\
\hline 42 & .045 & .094 & 99.737 & & & & & & \\
\hline 43 & .037 & .078 & 99.815 & & & & & & \\
\hline 44 & .036 & .075 & 99.889 & & & & & & \\
\hline 45 & .019 & .039 & 99.928 & & & & & & \\
\hline 46 & .016 & .033 & 99.962 & & & & & & \\
\hline 47 & .010 & .022 & 99.983 & & & & & & \\
\hline
\end{tabular}

\section{Results of the Confirmatory Factor Analysis}

After exploratory factor analysis, Confirmatory Factor Analysis (CFA) was run to verify the extracted model. Prior to CFA, the internal consistency of the entire inventory and that of its subscales were calculated via Cronbach's alpha. Cronbach's alpha values for the entire inventory and of its subscales were obtained as follows: $0.799,0.850,0.787,0.734,0.767,0.591,0.788$,
767, and 0.601 respectively, indicating high internal reliability. The results of the CFA confirmed an eightfactor model in which all the loadings between the indicators and the latent factors as well as the covariance among the factors were significant at ( $\mathrm{p}$ value $<.05)$. Figure 2 shows the path diagram of the model. 
Extraction Method: Principal Component Analysis.

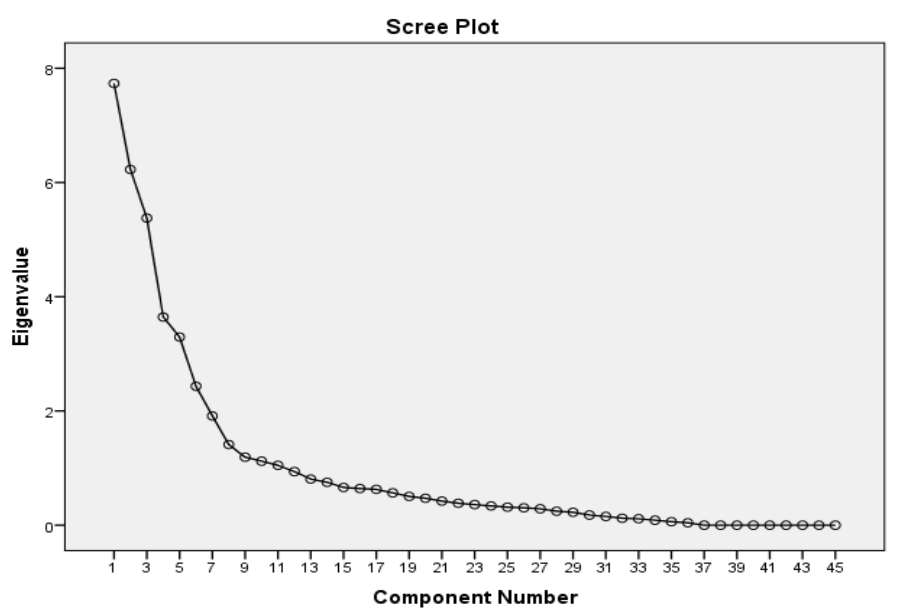

Figure 1. Scree plot

Table 4.Factor loadings for Exploratory Factor Analysis with varimax rotation of the questionnaire Rotated Component Matrix ${ }^{\mathrm{a}}$

\begin{tabular}{|c|c|c|c|c|c|c|c|c|c|}
\hline & \multirow{2}{*}{\multicolumn{8}{|c|}{ Component }} & \multirow{8}{*}{$\begin{array}{l}\text { Extraction Method: Principal Component Analysis. } \\
\text { Rotation Method: Varimax with Kaiser Normalization. } \\
\text { a. Rotation converged in } 15 \text { iterations. } \\
\text { Note. Extracted factors greater than } .3 \text { are in bold. }\end{array}$} \\
\hline & & & & & & & & & \\
\hline & \multicolumn{8}{|c|}{$2 \quad 3 \quad 4 \quad 5$} & \\
\hline Technical1 & .568 & & & & & & & & \\
\hline Technical2 & .414 & & & & & & & & \\
\hline Technical3 & .319 & & & & & & & & \\
\hline Technical4 & .880 & & & & & & & & \\
\hline Technical5 & .949 & & & & & & & & \\
\hline Inquery6 & & .899 & & & & & & -.347 & \\
\hline Inquery7 & & .888 & & & & & & & \\
\hline Inquery8 & & .811 & & & & & & & \\
\hline Inquery 9 & & .818 & & & & & & & \\
\hline Critical10 & & & .785 & & & & & & \\
\hline Critical11 & & & .394 & & & & & & \\
\hline Critical12 & & & .428 & & & & & & \\
\hline Critical13 & & & .657 & & & & & & \\
\hline Critical14 & & & .480 & & & & & & \\
\hline Critical15 & & & .418 & & & & & & \\
\hline Critical16 & & & .875 & & & & & & \\
\hline Critical17 & & & .396 & & & & & & \\
\hline Creativity 18 & & & & .424 & & & & & \\
\hline Creativity19 & & & & .511 & & & & & \\
\hline Creativity20 & & & & .934 & & & & & \\
\hline Teachercharacteristics 21 & & & & & .765 & & & & \\
\hline Teachercharacteristics 22 & & & & & .788 & & & & \\
\hline Teachercharacteristics 23 & & & & & .349 & & & & \\
\hline Teachercharacteristics 24 & .212 & & & & .344 & & & & \\
\hline Teachercharacteristics 25 & & & & & .302 & & & & \\
\hline Teachercharacteristics 26 & & & & & .389 & & & & \\
\hline Teachercharacteristics 27 & & & & & .239 & & & & \\
\hline Learner's factors 28 & & & & & & .440 & & & \\
\hline Learner' s factors 29 & & & & & & .214 & & & \\
\hline Learner' s factors 30 & & & & & & .250 & & & \\
\hline Learner'sfactors 31 & & & & & & .349 & & & \\
\hline Learner' s factors 32 & & & & & & .232 & & & \\
\hline Learner' sfactors 33 & & & & & & .235 & & & \\
\hline Learner' sfactors 34 & & & & & .312 & .358 & & & \\
\hline Learner sfactors 35 & & & & & & .302 & & & \\
\hline Learner' sfactors 36 & & & & & & .284 & & & \\
\hline Learner' sfactors 37 & .344 & & & & & .311 & & & \\
\hline Learner' sfactors 38 & & & & & & .343 & & & \\
\hline Learner'sfactors 39 & & & & & & .215 & & & \\
\hline Learner' sfactors 40 & .294 & & & & & & & & \\
\hline Obstacles 41 & & & & & & & & .746 & \\
\hline Obstacles 42 & & & & & & & & .678 & \\
\hline Obstacles 43 & & & & & & & & .658 & \\
\hline Obstacles 44 & & & & & & & & .392 & \\
\hline Advantage 45 & & & & & & & & & .460 \\
\hline Advantage46 & & & & & & & & & .407 \\
\hline Advantage47 & & & & & & & & & .492 \\
\hline Advantage 48 & .260 & & & & & & & & .732 \\
\hline
\end{tabular}




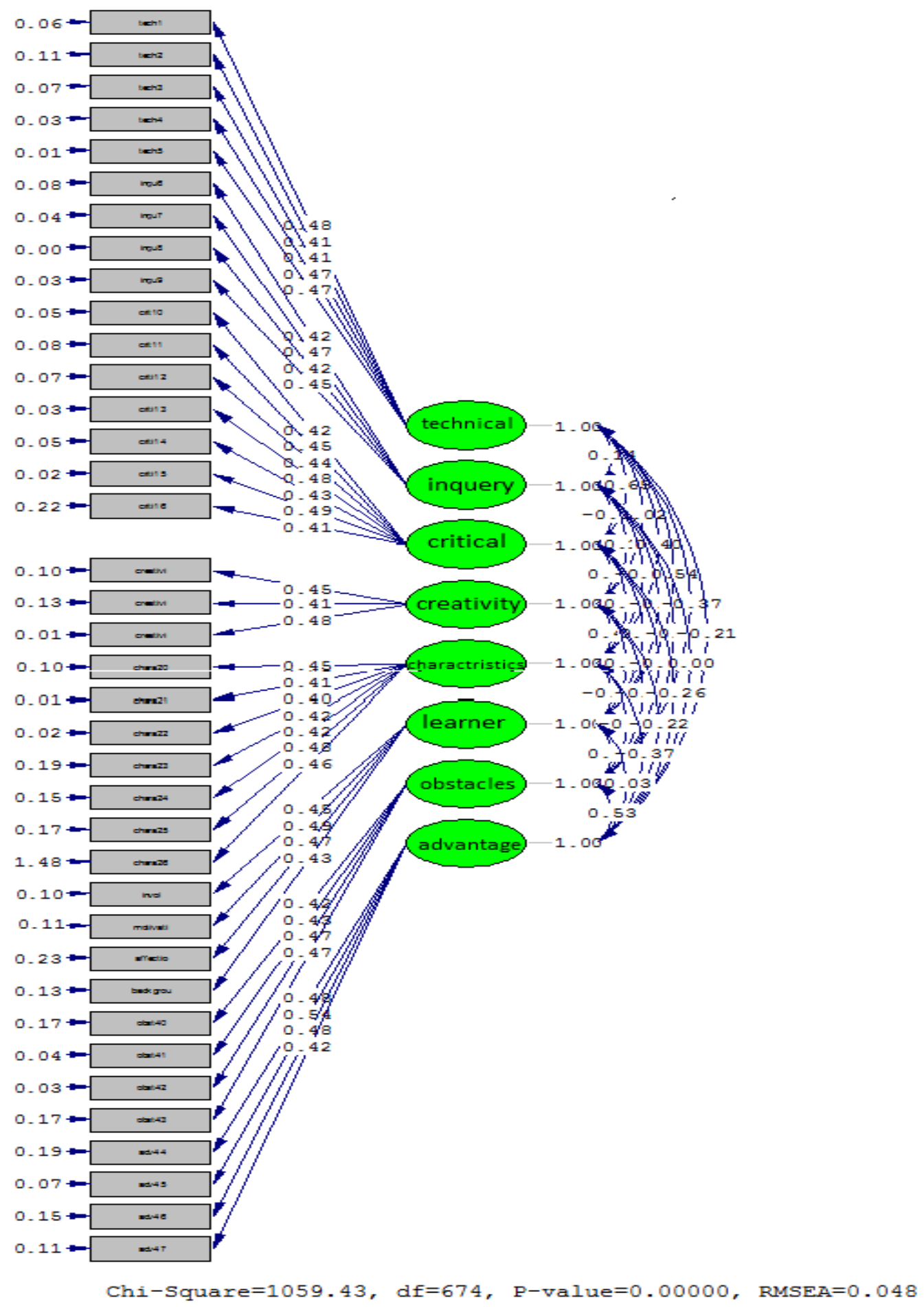

Figure 2. Path Diagram of the Model.

In order to assess the goodness of fit of the model the following indices were considered: Chi-square value < 3 , goodness fit index (GFI)>0.9 fit index $(\mathrm{CFI})$, the incremental fit index (IFI) $>0.9$, and RMSEA $<0.088$ (Kline, 2011; Sharma, 1996). Due to the absence of a single universally accepted criterion for assessing model fit (Sharma, 1996), the above-mentioned fit indices were used simultaneously. As evidenced in Table 5, the assessment indices for the dataset are less than the minimum cut point i.e. < 3 for normal Chi-Squared, < 0.06 for RMSEA, and greater than $>0.9$ for comparative fit index (CFI), and the incremental fit index (IFI), respectively. The goodness of fit indices, therefore, provides confirmation of the factorial structure of the questionnaire. In short, these pieces of evidence verify the construct validity of the scale. Hence, the null hypothesis stating that the Reflective Teaching Perception Questionnaire does not enjoy psychometric properties is refuted. The ultimate validated version of the questionnaire is provided in Appendix A. 
Table 5. Fit Indices for CFA Model

\begin{tabular}{|c|c|c|c|c|c|c|}
\hline \multirow[b]{3}{*}{ Current level } & \multicolumn{3}{|c|}{ Index Absolute Fit Indices } & \multicolumn{3}{|c|}{ Incremental Fit Indices } \\
\hline & Chi-Sq/df & AGFI & RMSEA & IFI & TLI & CFI \\
\hline & 1.57 & .93 & .048 & .99 & .90 & .91 \\
\hline Acceptable level & $>0.9$ & $>.85$ & $<.8$ & $>.9$ & $>.9$ & $>.9$ \\
\hline
\end{tabular}

\section{CONCLUSION}

In order to investigate EFL teachers' and learners' perceptions of reflective teaching initially, a 47-item scale was designed. In order to establish the construct validity of the newly designed instrument, both EFA and CFA were conducted whose results provided an 8factor solution. The implementation of factor analysis was determined by computation of the Bartlett sphericity test and the Kaiser-Meyer-Olkin measure of adequacy. The obtained results showed that the values of the Bartlett test were statistically significant, indicating that the correlation matrix was suitable for factoring. Kaiser-Meyer-Olkin measure was 0.771 indicating a medium level of adequacy of the correlation matrix for the implementation of factor analysis. The components at EFA stage emerged as follows: technical, inquiry, critical, creativity dimensions, learner's factors, teachers' characteristics, advantages of, and obstacles to reflective teaching. CFA also demonstrated statistical support for the eight extracted components. During the EFA, the items with small loading were deleted resulting in a 37 -item scale. According to the literature, one area of focus in reflective teaching is technical aspects of teaching which encompass primarily the instructional issues including classroom management, lesson planning, lesson delivery, learning and teaching strategies, activities, materials, used or taught by teachers (Farrell, 2004; Valli, 1997; Van Manen, 1977). The second factor, inquiry, is supported by the literature arguing that reflective teaching requires teachers to gather data about their teaching, assess their attitudes, beliefs, assumptions, and teaching practices (Richards \& Lockhart, 1996). The creativity dimension is also supported by the literature indicating that teaching without reflection leads to conformity and routinized practice, which can hinder creating novel insights (Farrell, 2007). Adopting reflective practice as Gunn (2010) asserts, "prevents teachers from falling into an attitude of routine, repetitive one-size-fits-all teaching" (p. 208). In other words, reflection can act as a shield against routine actions (Farrell, 2007). Teachers need to apply different approaches, creatively integrate different frameworks and models of practice, weigh up their practices, and reflect upon their teaching practices so as to become competent and professional teachers. Critical dimension of reflection is also in line with the literature (Hatton \& Smith, 1995; Jay \& Johnson, 2002). The advocates of reflective practice stress that adopting reflective practice is not restricted to the events within the confines of the classroom rather it includes the influence of the larger social and political contexts (Bartlett, 1990; Jay \& Johnson, 2002; Larrivee, 2008). Teachers are to "transcend the technicalities of teaching and think beyond the need to improve instructional techniques" (Bartlett, 1990, p. 204), and take into account issues of justice, equity, and morality, race, gender, and social class, paving the ways for students empowerment (Akbari, 2007) by providing students with knowledge, debate, and dialogue about pressing social problems and assist them to appreciate their power as social agents (Giroux, 1988). As for the learner's factors, reflective teachers need to take into account students' interest, their background, feedback, and other students' factors in their teaching to improve their teaching practice. As acknowledged by the humanistic approach to learning, both affective and cognitive domains should be taken into account in learning (Rogers, 1983). Reflective teachers are characterized by good observation, self-awareness, and self-critique (Ghaye, 2011). As noted by Akbari (2007) and Farrell (2007), reflection emancipates teachers from impulsive and routine behaviors, enabling them to construct and deconstruct their daily experiences in a manner that results in consciousness raising and deeper understanding about teaching. Workload, limited time, limited autonomy, lack of critical thinking, lack of support in their teaching program are frequently reported as the main obstacles to reflective teaching.

This line of inquiry raises language teachers' consciousness of the significance of reflection in effective language teaching in EFL context. Such awareness encourages them how to reflect and how to enhance their teaching practices. Promoting reflective orientation to teaching among teachers is crucial so as to raise teachers' awareness towards pedagogical, contextual, and ethical factors which would in turn contribute to improvement of themselves and their situation. The present study added creativity dimension, usefulness of, and barriers to reflective teaching which have not been included in the previous inventories (e.g., Young, 1989).

The newly designed instrument can be used in educational settings to assess teachers' perceptions as well as learners' perceptions concerning the significance of reflective teaching. Such awareness of significance of reflective teaching contributes to determine what to include in classroom curricula to implement a reflective approach in class. The categories posited by the present study can be offered as a 
heuristic device with the intent of contributing to an understanding of reflection for learning and professional development in teaching education programs. The findings of current research might be of value to the instructors of teacher education programs as they are encouraged to have a fresh look at their practices and policies; to customize techniques that promote reflective approach to teaching practices, to acquaint teachers with reflective practice. Given the contextual factors may play a role in the validity of any instrument, hence some modifications might be felt once the scale is applied to other settings.

\section{REFERENCES}

Akbari, R. (2007). Reflections on reflection. A critical appraisal of reflective practices in L2 teacher education. System, 35(2), 192-207. doi: $10.1016 /$ j.system.2006.12.008

Alger, C. (2006). What went well, what didn't go so well: Growth of reflection in pre-service teachers. Reflective Practice, 7(3), 287-301. doi: 10.1080/14623940600837327

Bartlett, L. (1990). Teacher development through reflective teaching. In J. C. Richards \& D. Nunan (Eds.), Second language teacher education (pp. 202- 214). Cambridge: CUP.

Dewey, J. (1933). How we think: A restatement of the relation of reflective thinking to the educative process. Boston: D.C. Heath and Co.

Dörnyei, Z. (2007). Research methods in applied linguistics: Quantitative, qualitative, and mixed methodologies. Oxford: Oxford University Press.

Dörnyei, Z., \& Taguchi, T. (2010). Questionnaires in second language research. Construction, administration, and processing (2nd ed.). New York, NY - Abingdon: Routledge.

Farhady, H., Hezaveh, F. S., \& Hedayati, H. (2010). Reflections on foreign language education in Iran. Tesl-Ej, 13(4), 1-18.

Farrell, T. S. C. (2004). Reflective practice in action: 80 Reflections breaks for busy teachers. California: Corwin Press.

Farrell, T. S. C. (2007). Reflective language teaching: From research to practice. London: Continuum.

Farrell, T. S. C. (2015). Promoting teacher reflection in second language education: A framework for TESOL professionals. New York, NY: Routledge.

Ghaye, T. (2011). Teaching and learning through reflective practice: A practical guide for positive action. London: Routledge.

Giroux, H. A. (1988). Teachers as intellectuals: Toward a critical pedagogy of learning. South Hadley, MA: Bergin Garvey.

Gunn, C. L. (2010). Exploring MA TESOL student resistance to reflection. Language Teaching Research, 14(2), 208-223. doi: $10.1177 / 1362168810363940$

Hatton, N., \& Smith, D. (1995). Reflection in teacher education: Towards definition and implementation.
Teaching and Teacher Education, 11(1), 22-49. doi: 10.1016/0742-051X(94)00012-U

Jay, J. K., \& Johnson, K. L. (2002). Capturing complexity: A typology of reflective practice for teacher education. Teaching and teacher education, 18(1), 73-85. doi: 10.1016/S0742051X(01)00051-8

Kayapınar, U., \& Erkuş, A. (2009). Measuring teacher reflection: Development of TRS. Eurasian Journal of Educational Research, 37, 144-158.

Kember, D., Leung, D. Y. P, Jones, A., Yuen Loke, A., Mckay, J., Sinclair, K., Tse, H., Webb, C., Yuet Wong, E. K., \& Yeung, E. (2000). Development of a questionnaire to measure the level of reflective thinking. Assessment \& Evaluation in Higher Education, 25(4), 381-395. doi: $10.1080 / 713611442$

Kline, R. B. (2011). Principles and practice of structural equation modeling. New York, NY: Guilford.

Larrivee, B. (2008). Development of a tool to assess teachers' level of reflective practice. Reflective Practice, 9(3), 341-360. doi: $10.1080 / 14623940802207451$

Mathews, N. (2012). Reflective classroom practice for effective classroom instruction. International Education Studies, 5(3) 205-211. doi: 10.5539/ies.v5n3p205

Pallant, J. (2011). SPSS Survival Manual: A step by step guide to data analysis using SPSS (4th ed.). Australia: Allen \& Unwin.

Pedro, J. Y. (2005). Reflection in teacher education: exploring pre-service teachers' meanings of reflective practice. Reflective Practice, 6(1), 49-66. doi: 10.1080/1462394042000326860

Pennington, M. (1992). Reflecting on teaching and learning: A development focus for the second language classroom. Kowloon: City Polytechnic of Hong Kong.

Richards, J. C., \& Lockhart, C. (1996). Reflective teaching in second language classrooms (6th ed.). New York: Cambridge University Press.

Richardson, V., \& Placer, P. (2001). Teacher change. In V. Richardson (Ed.), Handbook of research on teaching (pp. 905-947).Washington, DC: American Educational Research Association.

Rogers, C. R. (1983). Freedom to learn for the 80's. Columbus, OH: Merrill Publishing Company.

Schön, D. (1987). Educating the reflective practitioner. San Francisco: Jossey Bass.

Sharma, S. (1996). Applied multivariate techniques. New York: John Wiley \& Sons, Inc.

Shulman, L. (1987). Knowledge and teaching foundations of the new reform. Harvard Educational Review, 57(1) 2-21. doi: 10.17763/haer.57.1.j463w79r56455411

Valli, L. (1997). Listening to other voices: A description of teacher reflection in the United States. Peabody Journal of Education, 72(1), 67-88. doi: 10.1207/s15327930pje7201_4 
Van Manen, M. (1977). Linking ways of knowing with ways of being practical. Curriculum Inquiry, 6(3), 205-228. doi: 10.1080/03626784.1977.11075533

Williams, M., \& Burden, R. L. (1997). Psychology for language teachers: A social constructivist approach. Cambridge: Cambridge University Press.
Young, J. R. (1989). Pre-service teachers' written reflection: The effect of structured training on pedagogical thinking. Unpublished masters' thesis, Brigham Young University, Provo, Utah.

Zeichner, K. M., \& Liston, D. P. (1996). Reflective teaching: An introduction. Mahwah, NJ: L. Erlbaum Associates. 


\section{Appendix A: Reflective Teaching Attitude Scale (English Version)}

Dear Participant,

Please check the statements that describe the way you think about REFECLTIVE TEACHING. There are no right or wrong answers. We are only interested in your responses to the questionnaire. The information will be used for research purposes only. Thank you very much for your cooperation and contribution.

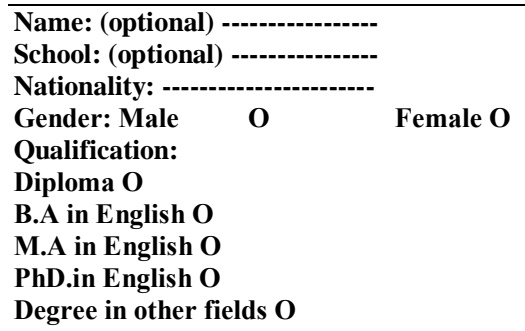

English Teaching Experience:

Less than one-year 0

1-2 years $O$

3-5 years $O$

5-10 years $O$

More than 10 years $O$

Would you like to receive an electronic copy of the study results? Yes O No O

Email address.

Key: 5: Very Significant, 4: Significant, 3: Undecided, 2: Slightly Significant, 1: No Significant

Thanks for Your Cooperation:-)

\begin{tabular}{|c|c|c|c|c|c|}
\hline Technical Dimension & 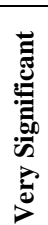 & 荀 & 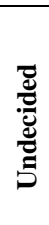 & 总 & 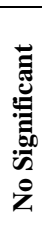 \\
\hline $\begin{array}{l}\text { 1. Reflective teaching requires the teacher to focus on teaching methods, } \\
\text { the efficiency of instruction in reaching the determined goals. }\end{array}$ & 5 & 4 & 3 & 2 & 1 \\
\hline $\begin{array}{l}\text { 2. Reflective teaching requires the teacher to examine their values and } \\
\text { beliefs } \\
\text { about teaching and learning. }\end{array}$ & 5 & 4 & 3 & 2 & 1 \\
\hline $\begin{array}{l}\text { 3. Reflective teaching requires the teacher to seek materials that meet } \\
\text { students' backgrounds, interests, and needs. }\end{array}$ & 5 & 4 & 3 & 2 & 1 \\
\hline $\begin{array}{l}\text { 4. Reflective teaching requires the teacher to focus on classroom } \\
\text { management, and establishing learning environment. }\end{array}$ & 5 & 4 & 3 & 2 & 1 \\
\hline $\begin{array}{l}\text { 5. Reflective teaching requires the teacher to recall and evaluate his/her } \\
\text { teaching experiences as a means of improving future ones. }\end{array}$ & 5 & 4 & 3 & 2 & 1 \\
\hline \multicolumn{6}{|l|}{ Inquiry Dimension } \\
\hline $\begin{array}{l}\text { 6. Reflective teaching requires the teacher to think and gather data about } \\
\text { his/her teaching, use the information obtained as a basis for improvement } \\
\text { of teaching. }\end{array}$ & 5 & 4 & 3 & 2 & 1 \\
\hline $\begin{array}{l}\text { 7. Reflective teaching requires the teacher to use different methods (e.g., } \\
\text { recording, observation, etc.) in inquiring or tackling a problem. }\end{array}$ & 5 & 4 & 3 & 2 & 1 \\
\hline $\begin{array}{l}\text { 8. Reflective teaching requires the teacher to reconstruct mentally when a } \\
\text { problem arises on the spot. }\end{array}$ & 5 & 4 & 3 & 2 & 1 \\
\hline $\begin{array}{l}\text { 9. Reflective teaching requires the teacher to discuss and analyze with } \\
\text { others the problems she encounter in his/her classroom to tackle them. }\end{array}$ & 5 & 4 & 3 & 2 & 1 \\
\hline \multicolumn{6}{|l|}{ Critical Dimension } \\
\hline $\begin{array}{l}\text { 10. Reflective teaching requires the teacher to develop critical thinking in } \\
\text { himself/herself and students. }\end{array}$ & 5 & 4 & 3 & 2 & 1 \\
\hline $\begin{array}{l}\text { 11. Reflective teaching requires the teacher to critically examine his/her } \\
\text { practices and find new ideas and puts these ideas into practice in order to } \\
\text { develop his/her performance and improve students' learning }\end{array}$ & 5 & 4 & 3 & 2 & 1 \\
\hline $\begin{array}{l}\text { 12. Reflective teaching requires the teacher to challenge the taken for } \\
\text { granted practices and assumptions. }\end{array}$ & 5 & 4 & 3 & 2 & 1 \\
\hline $\begin{array}{l}\text { 13. Reflective teaching requires the teacher to consider issues of justice, } \\
\text { equity, and morality as she designs his/her practice. }\end{array}$ & 5 & 4 & 3 & 2 & 1 \\
\hline
\end{tabular}




\begin{tabular}{|c|c|c|c|c|c|}
\hline $\begin{array}{l}\text { 14. Reflective teaching requires the teacher to create an equitable } \\
\text { classroom. }\end{array}$ & 5 & 4 & 3 & 2 & 1 \\
\hline $\begin{array}{l}\text { 15. Reflective teaching requires the teacher to consider social; cultural; } \\
\text { political forces that influence education }\end{array}$ & 5 & 4 & 3 & 2 & 1 \\
\hline \multicolumn{6}{|l|}{$\begin{array}{l}\text { 16. Reflective teaching requires teachers to talk about less-discussed } \\
\text { topics, such as old age, AIDS, discrimination against women and } \\
\text { minorities, and poverty in class. }\end{array}$} \\
\hline \multicolumn{6}{|l|}{ Creativity Dimension } \\
\hline $\begin{array}{l}\text { 17. Reflective teaching requires the teacher to use available technology } \\
\text { in achieving instructional objectives. }\end{array}$ & 5 & 4 & 3 & 2 & 1 \\
\hline $\begin{array}{l}\text { 18. Reflective teaching wants the teacher to employ creative and } \\
\text { innovative approaches to classroom and school situations. }\end{array}$ & 5 & 4 & 3 & 2 & 1 \\
\hline $\begin{array}{l}\text { 19. Reflective teaching requires the teacher to construct his/her own } \\
\text { teaching approach from the integration of his/her own experiences and } \\
\text { theoretical frameworks or other outside experts. }\end{array}$ & 5 & 4 & 3 & 2 & 1 \\
\hline \multicolumn{6}{|l|}{ Characteristics of Reflective Teacher } \\
\hline $\begin{array}{l}\text { 20. A reflective teacher monitors, evaluates, and revises his/ her own } \\
\text { practice continuously. }\end{array}$ & 5 & 4 & 3 & 2 & 1 \\
\hline $\begin{array}{l}\text { 21.A reflective teacher is open to alternative perspectives and new } \\
\text { knowledge. }\end{array}$ & 5 & 4 & 3 & 2 & 1 \\
\hline 22. A reflective teacher has inquiry skills. & 5 & 4 & 3 & 2 & 1 \\
\hline $\begin{array}{l}\text { 23. A reflective teacher has a wide range of knowledge e.g. subject } \\
\text { matter and curriculum knowledge, sociocultural awareness, and } \\
\text { knowledge of pedagogy. }\end{array}$ & 5 & 4 & 3 & 2 & 1 \\
\hline $\begin{array}{l}\text { 24. A reflective teacher enhances professional growth through } \\
\text { collaboration and dialogue with colleagues. }\end{array}$ & 5 & 4 & 3 & 2 & 1 \\
\hline $\begin{array}{l}\text { 25. A reflective teacher consults with literature available, books, } \\
\text { searches the internet to keep in touch with recent advancement in his/her } \\
\text { field. }\end{array}$ & 5 & 4 & 3 & 2 & 1 \\
\hline \multicolumn{6}{|l|}{ Learner's Issues } \\
\hline $\begin{array}{l}\text { 26. Reflective teaching requires the teacher to consider students as active } \\
\text { participants rather than passive recipients during the learning process. }\end{array}$ & 5 & 4 & 3 & 2 & 1 \\
\hline $\begin{array}{l}\text { 27. Reflective teaching requires the teacher to encourage students to be a } \\
\text { researcher, be problem poser, and critical thinker. }\end{array}$ & 5 & 4 & 3 & 2 & 1 \\
\hline $\begin{array}{l}\text { 28. Reflective teaching wants the teacher to take into account learners' } \\
\text { cognitive factors including background, individual differences, abilities }\end{array}$ & 5 & 4 & 3 & 2 & 1 \\
\hline $\begin{array}{l}\text { 29. Reflective teaching wants the teacher to take into accounts learners' } \\
\text { affective factors including feedback, motivation, involvement. }\end{array}$ & 5 & 4 & 3 & 2 & 1 \\
\hline \multicolumn{6}{|l|}{ Obstacles } \\
\hline $\begin{array}{l}\text { 30. A reflective teacher is restricted by contextual factors and schools } \\
\text { realities including mandated curriculum, large classroom, authorities, } \\
\text { principles, and parents. }\end{array}$ & 5 & 4 & 3 & 2 & 1 \\
\hline 31. A reflective teacher is restricted by workload and time. & 5 & 4 & 3 & 2 & 1 \\
\hline $\begin{array}{l}\text { 32. Lack of critical thinking attitude restricts reflection on the part of } \\
\text { teacher. }\end{array}$ & 5 & 4 & 3 & 2 & 1 \\
\hline $\begin{array}{l}\text { 33. Low motivation and low level of study restrict reflection on the part } \\
\text { of teacher. }\end{array}$ & 5 & 4 & 3 & 2 & 1 \\
\hline \multicolumn{6}{|l|}{ Advantages } \\
\hline $\begin{array}{l}\text { 34. Reflective teaching enables the teacher to depart from routine } \\
\text { practices. }\end{array}$ & 5 & 4 & 3 & 2 & 1 \\
\hline $\begin{array}{l}\text { 35. Reflective teaching makes the teacher think of the new teaching } \\
\text { method to improve students' learning. }\end{array}$ & 5 & 4 & 3 & 2 & 1 \\
\hline $\begin{array}{l}\text { 36. Reflective teaching enables the teacher to recognize their strengths } \\
\text { and weaknesses. }\end{array}$ & 5 & 4 & 3 & 2 & 1 \\
\hline $\begin{array}{l}\text { 37. Reflective teaching paves the way toward teacher's professional } \\
\text { development through cognitive and affective changes in their learning, } \\
\text { in their socialization, improvement. }\end{array}$ & 5 & 4 & 3 & 2 & 1 \\
\hline
\end{tabular}

